\begin{tabular}{|c|c|}
\hline $\begin{array}{l}\text { MINING AND METALLURGY INSTITUTE BOR } \\
\text { UDK: } 622\end{array}$ & $\begin{array}{l}\text { ISSN: 2334-8836 (Štampano izdanje) } \\
\text { ISSN: 2406-1395 (Online) }\end{array}$ \\
\hline UDK: $628.161 .1: 681.51(045)=111$ & DOI:10.5937/MMEB1501117E \\
\hline
\end{tabular}

\title{
NEW APPROACH FOR WATER QUALITY ANALYSIS AND MODELING
}

\begin{abstract}
Watercourses present a special case of water reservoirs. Regardless to the method of their investigation, there is still a search for the convenient method for processing of collected measurements of water quality parameters. Research direction was defined by the EU directive framework for aquatic bodies. Taking into consideration the existing methods for water quality analysis, this paper presents a proposal of a new method for analysis and modeling the aquatic body behavior. The measurements conducted at five stations on the river Ibar in the period from 2007 to 2012 are used as a basis. The basic method is based on multivariable analysis of unevenly time spaced measuring data. The basis was the correlation analysis that defined dependent parameters for determination the SWQI indices. Analyses have shown that the obtained results can be used for establishing an integral monitoring the water quality of aquatic system of the river Ibar. Also, they pointed out the possible directions for measurement and analysis upgrading.
\end{abstract}

Keywords: modeling, water reservoirs, SWQI, measurement BOD-5

\section{INTRODUCTION}

Humans have evolved from psychologically relatively insignificant consumers to the clever, intellectual beings and geochemical users of external energy resources and materials for building of their civilization and enhancement of domination. People waste 10 to 20 times (on the northern hemisphere 50 to 100 times) more energy than what is needed for their metabolism. Disruption of water surroundings indirectly caused by the energy consumption can exceed the one that causes ejection of excretions (Figure 1). Most of the energy that industrial society uses as its advantage (making heat, landscape management, urban structure, agriculture, forestry, geological studies, building of dams) in the end affects and disrupts the ecosystem. People - as terrestrial beings - directly affect the primarily terrestrial environment; but, since terrestrial and aquatic ecosystems are connected and due to the sensibility of the latter, the emphasized impact of civilization on the ecology primarily is reflected on the aquatic ecosystem. Many consequences of energy dissipation are also noticeable in the atmosphere, which behaves as the efficient assembly line for many pollutants. Human power to disturb environment tends to go above technological capabilities to respond to impact on the environment [1].

Ecosystem can be defined as the unit of environment where, as the result of solar energy input, biological community (primary producers, consumers and decomposers) is reflected; energy flow is used for organi

\footnotetext{
* Pristina University, Faculty of Technical Sciences, Kosovska Mitrovica, Knjaza Miloša 7, e-mail:elezkm@yahoo.com

${ }^{* * *}$ Nis University, Faculty of Technology, Leskovac

**** University of Belgrade, Institute for Multidisciplinary Research, Belgrade
} 
zation of the system and is followed by the cycles of water, nutrients and other elements and by the life cycle through different food consumers at different levels. Members of the ecosystem are connected by different feedbacks (homeostasis) and as so are adapted to coexistence for the purpose of mutual progression. Network of control and balances includes many transfers of organic and inorganic substances - a network of food, nutrients, allelochemicals - and makes ecosystem a functional unit [2].

The Second Law of Thermodynamics states that each spontaneous process shall be followed by increase of entropy:

$\mathrm{d} S$ (source, drain) $+\mathrm{d} S($ ecosystem $) \geq 0$.

Due to the condition $\mathrm{d} S$ (source, drain) $>0$, ecosystem entropy can decline, that is, to be:

$$
-\mathrm{d} S \text { (ecosystem) } \leq \mathrm{d} S \text { (source, drain). }
$$

Declination is seen in the arrangement of ecosystem and in the presence of incredibly high integration of energy as living beings. Their organization is maintained at the expense of increasing entropy in the environment.

Up to now, it was tried to approach different subjects in a quantitative and rigorous way. In this research, on the contrary, we have to rely on qualitative and often speculative arguments, because our understanding of elasticity of aquatic ecosystem is seriously hampered by the lack of theoretical and sufficient empirical information on the effects of physical and chemical disorders of aquatic ecosystems [3].

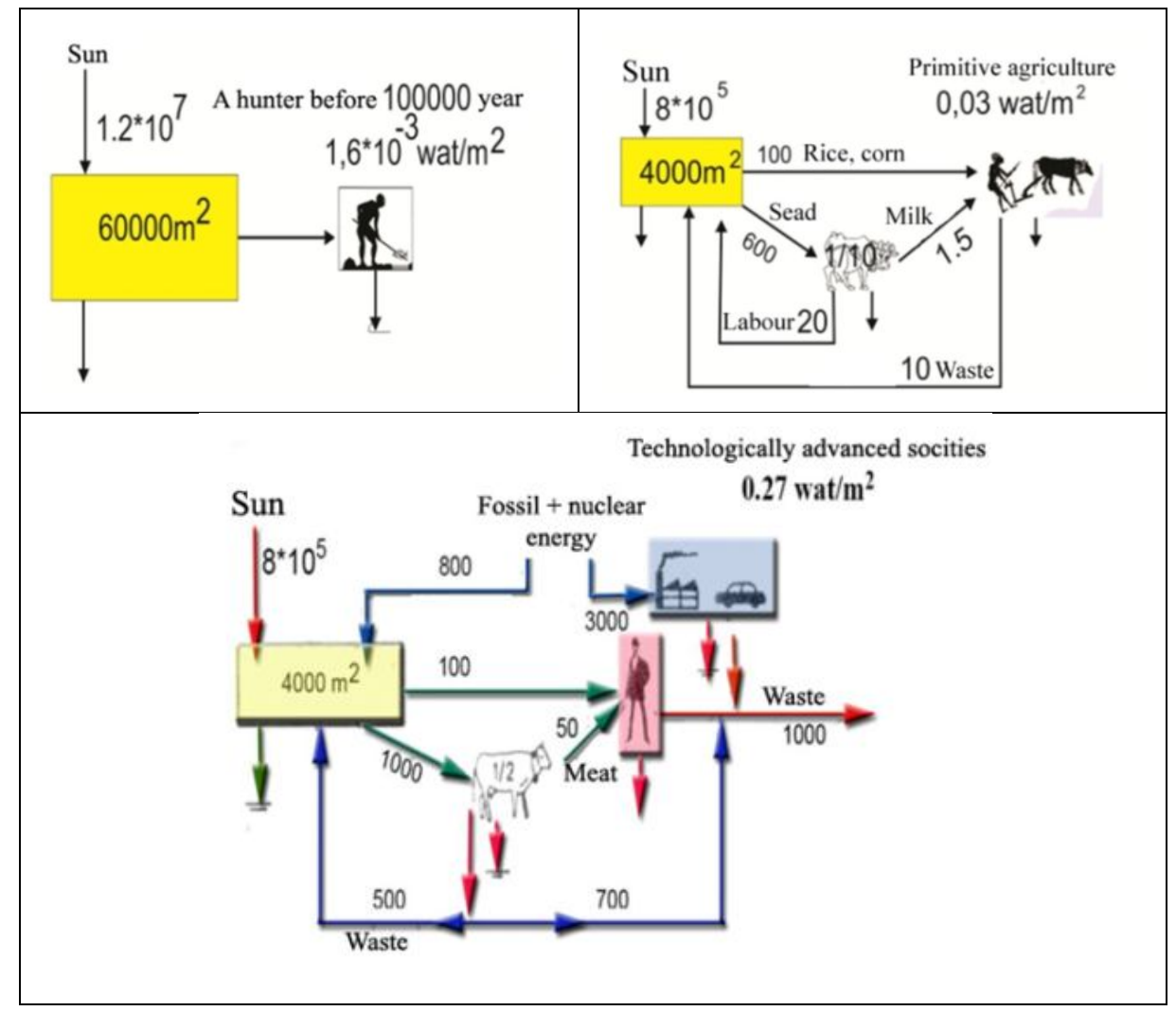

Figure 1 Energy and land demands of the primitive and modern man 
For preservation of our culture and civilization and the improvement of life quality, and especially for food production for growing the world population, it is necessary to continue to depend on the utilization of technology and energy. Social criteria and growing pressure for social equality must simultaneously establish the scientific and technological development.

Watercourses represent a special case of water reservoirs. From the aspect of water quality analysis, watercourses present a set of interactions of biodiversities and human (anthropogenic) activities, which are variable in time and space. If changes occur in one part of the watercourse, after a certain period of time, it is either distributed throughout the water body or transferred to the other place. Monitoring of water quality in watercourse presents a problem. Status of watercourses, that is the water quality, currently is determined by methodology of conventional sampling followed by measurement of values of appropriate parameters.

Regardless the fact that our country falls into areas with relatively developed aquatic network, it is not certain that, if this trend of pollution continues, the water itself shall become deficient resource.

For the time being, the current system for measuring the water quality, index of water quality and its variations applied in our country is SWQI (SERBIAN WATER QUALITY INDEX) developed by the Serbian Environmental Protection Agency. The idea of setting or defining the such index is to use one number to clearly indicate the quality of aquatic body that would be understandable and would point out the potential existing problems to wider community. Selection of parameters used for determination the water quality index most closely reflects the water quality, whereby each of those parameters has different weigh in the analysis. System itself indicates the existence of certain "partiality" of the water quality index, which does not necessarily mean that the index is not good, but still indicates a lack of explicitness of the index itself [4].

Another problem is the lack of representative sampling methodology. Sampling presents a crucial part of each measurement methodology. If one looks at development of measurement techniques, measurement methodology, data processing as well as modeling, all these areas have experienced the significant improvements in methodology, quality and so on, except in the way of sampling the entity for analysis.

Problem of the water quality analysis in watercourses is enlarged by the fact that a sample is valid only for the location and time of sampling, therefore the time period between sampling and analysis of sample is very important.

\section{METHODOLOGY \\ (ACQUISITION AND DATA PROCESSING, MODELING)}

For the purpose of analysis and possible upgrading the integral monitoring of watercourses quality, the analysis of existing data for the river Ibar and five sampling stations during the period 2007-2012 were realized. Also, an appropriate calculated SWQI was conducted. The paper presents the analysis of data for the river Ibar and five sampling stations for the period 2007-2012 on the basis of calculated values of SWQI. The aim of this research is to estimate a possibility for upgrading the integral monitoring of the river Ibar water quality for the time period from 2007 to 2012 on the basis of data analysis.

The results are based on the obtained measurements of the RHMS of Serbia and Serbian Environmental Protection Agency. The mean annual values of the parameters used for calculation of SWQI during the period from 2007 to 2012, and the mean annual values of SWQI for the same period are presented in Table 1 [5]. 
Table 1 SWQI of the river Ibar water quality for the period 2007-2012.

\begin{tabular}{|l|c|c|c|c|c|c|}
\hline Parameters & $\mathbf{2 0 0 7}$ & $\mathbf{2 0 0 8}$ & $\mathbf{2 0 0 9}$ & $\mathbf{2 0 1 0}$ & $\mathbf{2 0 1 1}$ & $\mathbf{2 0 1 2}$ \\
\hline Temperature $\left({ }^{\circ} \mathrm{C}\right)$ & 12.78 & 12.47 & 11.00 & 11.31 & 11.46 & 11.79 \\
\hline $\mathrm{pH}$ & 8.43 & 8.42 & 8.36 & 8.24 & 8.47 & 8.48 \\
\hline $\begin{array}{l}\text { Conductivity } \\
(\mu \mathrm{S} / \mathrm{cm})\end{array}$ & 416.20 & 448.62 & 428.73 & 433.33 & 447.08 & 432.50 \\
\hline $\begin{array}{l}\text { Oxygen saturation } \\
(\%)\end{array}$ & 99.14 & 93.49 & 94.22 & 99.63 & 95.5 & 95.43 \\
\hline BOD-5 (mg/l) & 3.03 & 2.76 & 2.30 & 2.37 & 2.12 & 2.02 \\
\hline $\begin{array}{l}\text { Suspended matter } \\
(\mathrm{mg} / \mathrm{l})\end{array}$ & 21.05 & 25.78 & 24.24 & 21.45 & 26.95 & 27.41 \\
\hline Total N (mg/l) & 1.73 & 2.10 & 1.42 & 0.93 & 1.21 & 0.86 \\
\hline $\begin{array}{l}\text { Orthophosphate } \\
(\mathrm{mg} / \mathrm{l})\end{array}$ & 0.11 & 0.14 & 0.11 & 0.10 & 0.11 & 0.09 \\
\hline Ammonium $(\mathrm{mg} / \mathrm{l})$ & 0.02 & 0.01 & 0.03 & 0.25 & 0.14 & 0.24 \\
\hline $\begin{array}{l}\text { Coliform bacteria } \\
(\mathrm{u} 100 \mathrm{ml})\end{array}$ & 13483.33 & 15274.33 & 15150.00 & 14703.33 & 7714.60 & 174.65 \\
\hline SWQI & $\mathbf{7 8}$ & $\mathbf{7 7}$ & $\mathbf{8 1}$ & $\mathbf{7 8}$ & $\mathbf{8 1}$ & $\mathbf{8 2}$ \\
\hline
\end{tabular}

\section{RESULTS AND DISCUSSION}

Term ,correlation” originates from the Latin word "correlatio" mutual relationship. Term "correlation analysis" implies the measurement of the levels of stochastic interdependences, that is, measurement the degree of congruence of variances of the observed quantities in relative terms.

Coefficients of linear correlation or correlation index for nonlinear regression models are used for measurement the degree of correlations (dependences) between two variables. There are close relations between regression and correlation analysis. In practice, we are most often affected with occurrences that mutually influence, and therefore the study of existence of interrelations is of great importance. Study can be performed on the basis of basic set or on the basis of samples regarding basic set, and all this ca- rries a certain risk of error that can be controlled. Functional relation between occurrences can be deterministic (strictly determined-mathematical) or stochastic. Stochastic dependence between variables is expressed in many cases as the mean relation and has higher or lower variation of individual cases regarding the functional relation. Stochastic dependence is expressed conditionally by mathematical functions best approximated by the given empirical data with a certain selection error. The aim of regression analysis is to determine a functional analysis between the observed concepts, and correlation analysis to indicate the existence of relations between the analyzed entities.

Correlation analysis of parameters dependence and SWQI for the same time period is given in Figure 2 and Table $2[6,7]$. 


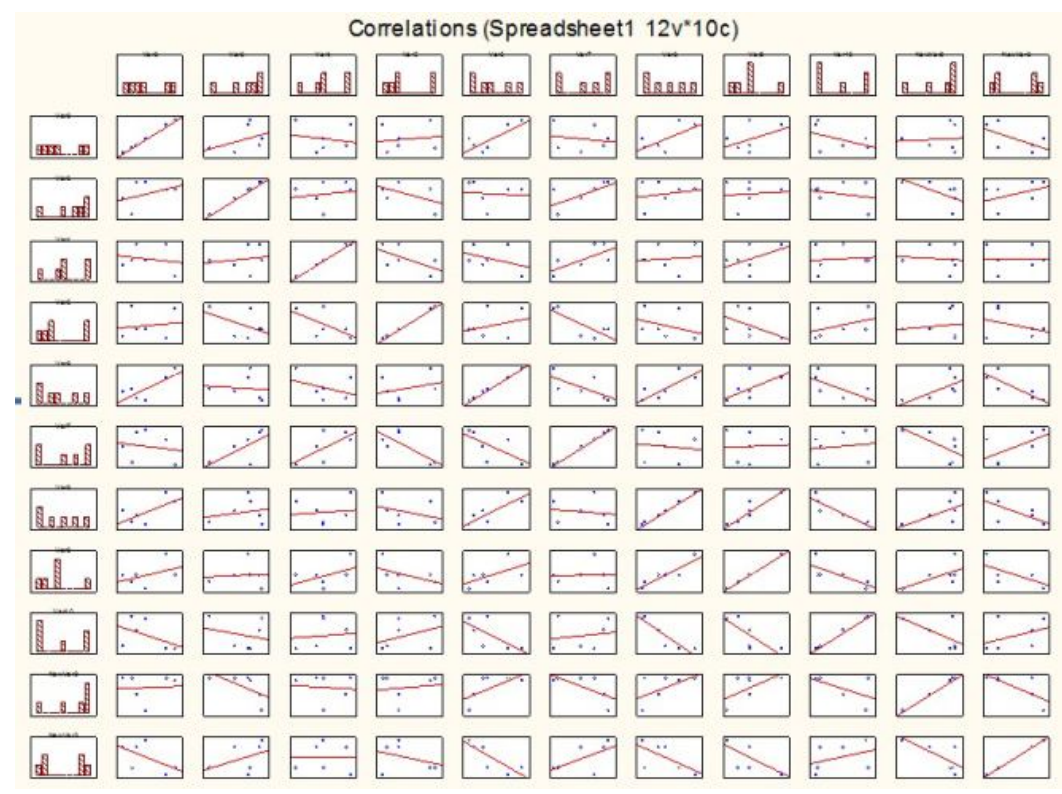

Figure 2 Graphical representation of correlation matrix

Table 2.Correlation analysis of SWQI and parameters for calculation

\begin{tabular}{|c|c|c|c|c|c|c|c|c|c|c|c|}
\hline & $\mathbf{T}\left({ }^{\circ} \mathbf{C}\right)$ & pH & $\begin{array}{l}\text { Cond. } \\
(\mu \mathrm{S} / \mathrm{cm})\end{array}$ & $\begin{array}{c}\text { Oxygen } \\
\text { saturat. } \\
(\%)\end{array}$ & $\begin{array}{l}\text { BOD }_{5} \\
(\mathrm{mg} / \mathrm{l})\end{array}$ & $\begin{array}{c}\text { Suspen. } \\
\text { solids } \\
\text { (mg/l) }\end{array}$ & $\begin{array}{c}\text { Total N } \\
(\mathbf{m g} / \mathbf{l})\end{array}$ & $\begin{array}{c}\text { Orto } \\
\mathbf{P} \\
(\mathrm{mg} / \mathrm{l})\end{array}$ & $\begin{array}{c}\mathrm{NH}_{3} \\
(\mathrm{mg} / \mathrm{l})\end{array}$ & \begin{tabular}{|c|} 
Coli- \\
form \\
bacteria
\end{tabular} & SWQI \\
\hline $\mathrm{T}\left({ }^{\circ} \mathrm{C}\right)$ & 1.00 & 0.42 & -0.18 & 0.14 & 0.78 & -0.18 & 0.65 & 0.43 & -0.44 & 0.07 & -0.58 \\
\hline $\mathrm{pH}$ & 0.42 & 1.00 & 0.16 & -0.48 & -0.09 & 0.68 & 0.20 & 0.08 & -0.23 & -0.63 & 0.42 \\
\hline $\begin{array}{l}\text { Cond. } \\
(\mu \mathrm{S} / \mathrm{cm})\end{array}$ & -0.18 & 0.16 & 1.00 & -0.59 & -0.37 & 0.67 & 0.10 & 0.47 & 0.10 & -0.09 & -0.01 \\
\hline $\begin{array}{l}\text { Oxygen } \\
\text { saturat. } \\
(\%)\end{array}$ & 0.14 & $\begin{array}{c}- \\
0.48\end{array}$ & -0.59 & 1.00 & 0.29 & -0.79 & -0.33 & -0.47 & 0.37 & 0.14 & -0.33 \\
\hline $\begin{array}{l}\text { BOD-5 } \\
(\mathrm{mg} / \mathrm{l})\end{array}$ & 0.78 & $\begin{array}{c}- \\
0.09\end{array}$ & -0.37 & 0.29 & 1.00 & -0.64 & 0.79 & 0.58 & -0.68 & 0.65 & -0.82 \\
\hline $\begin{array}{l}\text { Suspen. } \\
\text { solids } \\
(\mathrm{mg} / \mathrm{l})\end{array}$ & -0.18 & 0.68 & 0.67 & -0.79 & -0.64 & 1.00 & -0.13 & 0.05 & 0.15 & -0.66 & 0.60 \\
\hline $\begin{array}{l}\text { Total N } \\
(\mathrm{mg} / \mathrm{l})\end{array}$ & 0.65 & 0.20 & 0.10 & -0.33 & 0.79 & -0.13 & 1.00 & 0.91 & -0.91 & 0.60 & -0.63 \\
\hline $\begin{array}{l}\text { Orto P } \\
(\mathrm{mg} / \mathrm{l})\end{array}$ & 0.43 & 0.08 & 0.47 & -0.47 & 0.58 & 0.05 & 0.91 & 1.00 & -0.75 & 0.61 & -0.63 \\
\hline $\begin{array}{l}\mathrm{NH}_{3} \\
(\mathrm{mg} / \mathrm{l})\end{array}$ & -0.44 & $\begin{array}{c}- \\
0.23\end{array}$ & 0.10 & 0.37 & -0.68 & 0.15 & -0.91 & -0.75 & 1.00 & -0.59 & 0.37 \\
\hline $\begin{array}{l}\text { Coliform } \\
\text { bacteria }\end{array}$ & 0.07 & $\begin{array}{c}- \\
0.63\end{array}$ & -0.09 & 0.14 & 0.65 & -0.66 & 0.60 & 0.61 & -0.59 & 1.00 & -0.73 \\
\hline SWQI & -0.58 & 0.42 & -0.01 & -0.33 & -0.82 & 0.60 & -0.63 & -0.63 & 0.37 & -0.73 & 1.00 \\
\hline
\end{tabular}


The results obtained by correlation analysis and presented in Table 2 show that there is no correlation between the measured parameters and calculated SWQI value. The only significant correlation exists between the parameter BOD-5 and SWQI. The analysis itself is interesting because SWQI is calculated on the basis of these parameters and between the measured parameters and SWQI should be linear dependence.

This means that between the measuring points in time there are uncontrolled changes caused by different influences or what is more likely by different pollutants placed along the river Ibar watercourse between the measuring stations. Although SWQI is calculated from the above parameters, correlation only exists between BOD-5 and SWQI, even though the index is calculated from all of the foregoing. This can be explained by the fact that each parameter is calculated with certain weight that disturbs correlation. The existence of correlation itself between BOD-5 and SWQI suggests that quick estimation of SWQI index can be performed based on monitoring the changes of BOD-5 values, as shown in Figure 3.

At this point, we would not enter into debate on value of weighted factors that are entered for each parameter for calculation of SWQI, as well as defining their values. Since the basis of this paper is the idea for improving the monitoring of integral quality of watercourses, that is, the river Ibar, BOD-5 parameter shall be analyzed as a possible indicator of SWQI index. For this analysis the normalized mean annual values of BOD-5 and SWQI were used for the period from 2007 to 2012, as shown in Figure 3 [7].

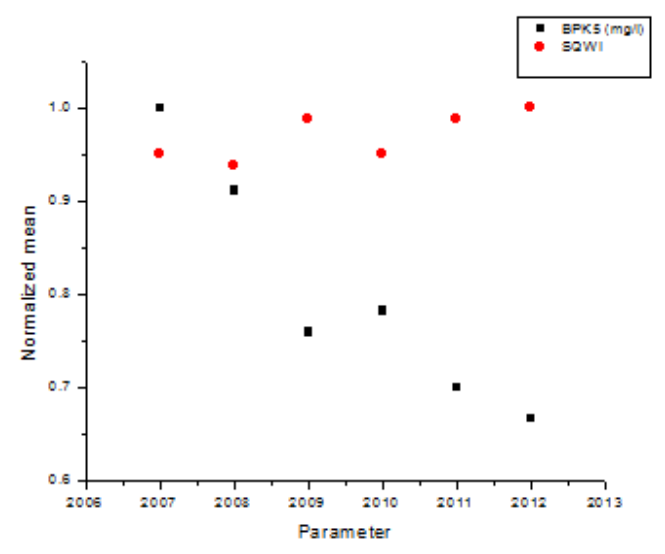

Figure 3 Normalized mean annual values of BOD-5 and SWQI along the river Ibar

As shown in Figure 3, the value change of SWQI follows the value change of BOD-5. This fact can be used to define the model for monitoring the pollution of aquatic body. Biological oxygen demand is quantity of oxygen necessary for biological decomposition of contaminated substances. From the aspect of self-purification of watercourses, the aeration and reaeration are the key processes. Organic pollution of aquatic environment activates a range of biological activities (bacteria, algae and fungi) that lead to conversion of organic matter to the final inorganic products. Reaeration and BOD-5 as two basic reactions during the process of self-purification of aquatic environment present the basis for determination the spatial and time distribution of dissolved oxygen, that is, oxygen balance. The result of these two processes 
presents the real content of dissolved oxygen along the whole watercourse. If calculation, methodology or model SWQI are analyzed, it cannot be clearly defined how the reaeration of aquatic environment is quantified. Therefore, it is necessary to define the potential pollutants (mainly organic matter) in the investigated water ourse. If we look at the distribution of measuring stations on aquatic body, we can define the general and potential pollutants at locations between the measuring stations. This defines a "tree of pollutants" and locations of potential pollutions of aquatic body. The tree of pollutants is shown in Figure 4 [7]. It can be seen that between each measuring station there is a pollutant with higher or lower intensity.

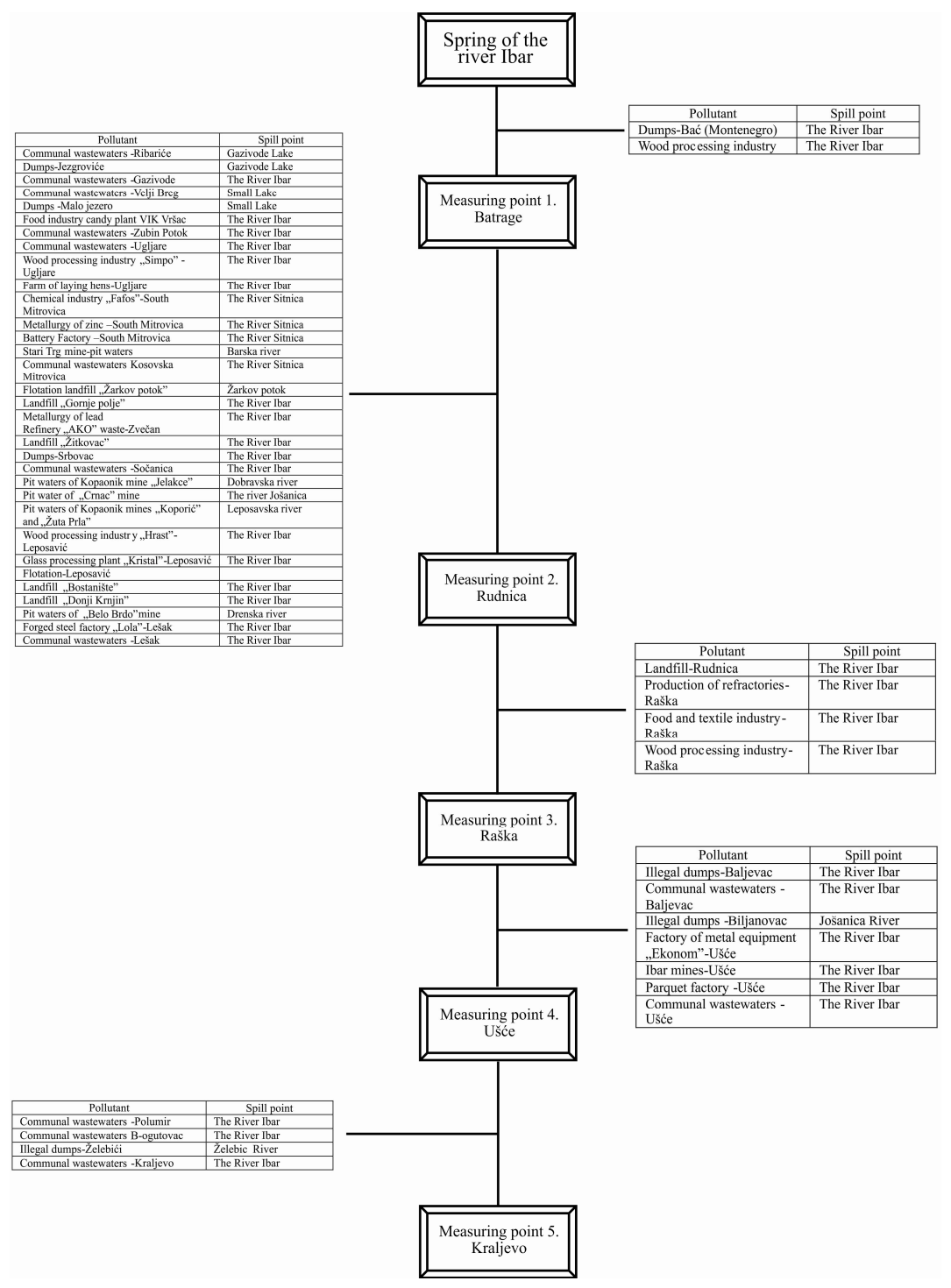

Figure 4 Tree of pollutants [7] 
It is difficult to determine the level of pollution, because there are no accurate data on quantity of waste material. As it can be seen, there is a reasonable assumption that some of the parameters and their variations will vary during the time and that thereby it will not significantly affect the value of SWQI. One of the representative water quality parameters is biological oxygen demand (BOD-5). The degree of water pollution by organic compounds is defined by the quantity of oxygen needed for oxidation the present biologically degradable elements of water performed by aerobic microorganisms. This quantity of oxygen is called biological oxygen demand (BOD). The needed quantity is proportional to the present quantity of organic matter. The temperature and time of degradation affect the value of $B O D$, that is, with an increase of temperature increases the speed and oxygen demand (biochemical oxidation). It can be considered that it takes 5 days for decomposition of major part (70-80\%) of present organic matters in darkness at the constant water temperature of $20^{\circ} \mathrm{C}$, and therefore is called BOD. BOD is not a typical pollutant, but a measure of oxygen quantity needed for bacteria and other microorganisms involved in stabilization of decomposition the organic matter during a certain period of time. BOD is the measure of oxygen consumption, or potential oxygen consumption. Liquid waste with high BOD can be harmful to the river if consumption of oxygen is large enough to cause anaerobic conditions.

The analysis of BOD change during the time along the watercourse given through the mean annual values for the period 20072012 per measurement point with standard deviations is presented in Figure 5 [7]. An increase in BOD towards the mouth of the river Ibar into West Morava indicates that the quantity of organic pollutant increases.

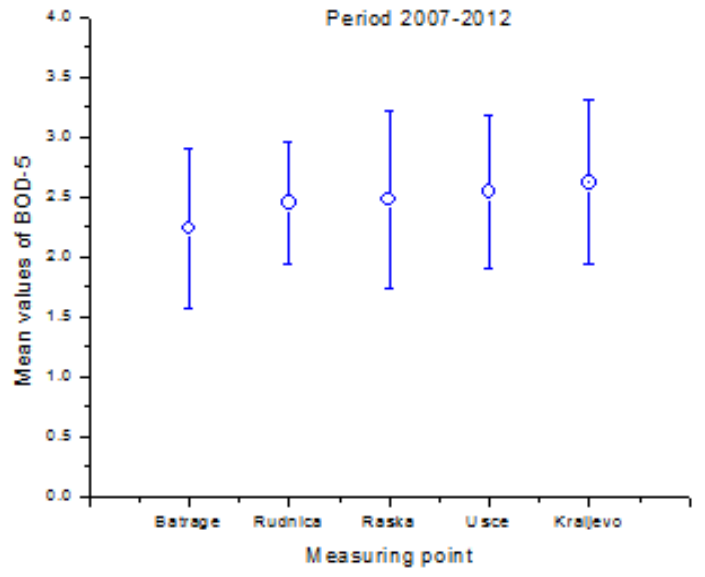

Figure 5 Mean annual values of BOD-5 for the period 2007-2012.

It is evident that there is an increasing trend of mean values per measuring stations toward mouth of the river Ibar into West Morava. Also, if measurement variation (standard deviation) is observed, it is possible to see that those deviations over the period of 6 years vary by measuring station or locations. Therefore, defining the tree of pollutants gains in importance because the time variations of measured parameters indicate the increased or reduced pollution (organic matters) at the measuring station and defined time period (2007-2012). 
However, if the coefficient of variation is analyzed as well as the changes of BOD over time and at measuring points, it can be seen that such change is not linear, which means that includes a random un controlled pollution between the measuring stations.

Statistical analysis of BOD changes for the period 2007-2012 is presented in Table 3 .

Table 3 Statistical analysis of BOD-5 value for the period 2007-2012.

\begin{tabular}{|l|c|c|c|c|c|c|c|c|c|}
\hline $\begin{array}{c}\text { Measuring } \\
\text { point }\end{array}$ & $\begin{array}{c}\text { Mean } \\
\text { value. }\end{array}$ & STD & $\begin{array}{c}\text { Stand. } \\
\text { Error mean } \\
\text { value }\end{array}$ & Variat. & $\begin{array}{c}\text { Mean } \\
\text { variations of } \\
\text { value of } \\
\text { absolu. } \\
\text { deviation }\end{array}$ & Min. & Mean & Max. \\
\hline Batrage & 2.24 & 0.672 & 0.084 & 0.452 & 0.299 & 0.524 & 0.6 & 2.23 & 3.6 \\
\hline Rudnica & 2.45 & 0.509 & 0.072 & 0.259 & 0.207 & 0.382 & 1.2 & 2.45 & 3.8 \\
\hline Raska & 2.48 & 0.747 & 0.086 & 0.558 & 0.300 & 0.581 & 1 & 2.3 & 5.2 \\
\hline Usce & 2.54 & 0.637 & 0.078 & 0.405 & 0.250 & 0.511 & 0.72 & 2.6 & 4 \\
\hline Kraljevo & 2.62 & 0.686 & 0.070 & 0.471 & 0.261 & 0.508 & 0.6 & 2.5 & 4.5 \\
\hline
\end{tabular}

Graph chart of minimum and maximum BOD value difference per measuring points is shown in Figure 6 [3]. It can be seen that maximum differences in the period from 2007 to 2012 were measured at the measuring station Raska.

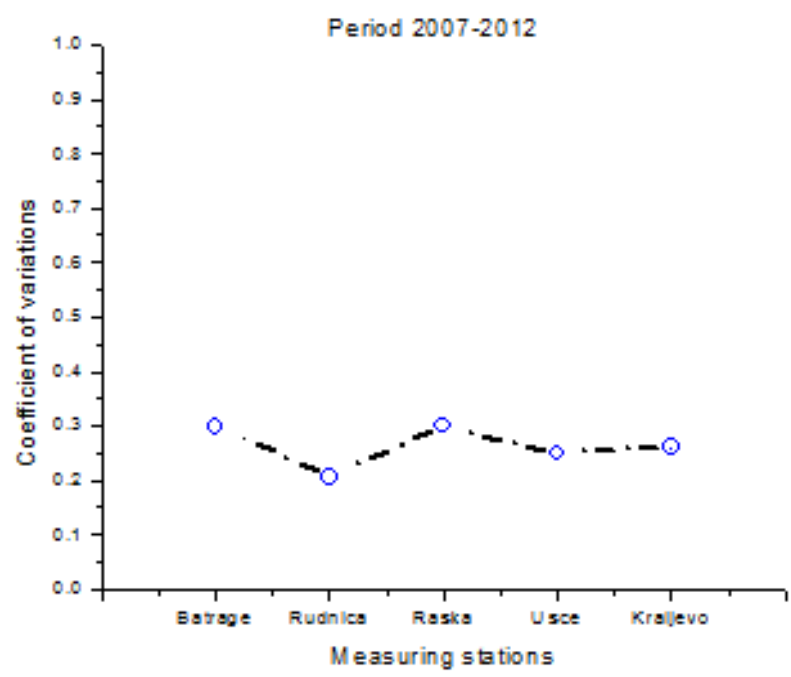

Figure 6 Differences of minimum and maximum BOD-5 values per measuring stations

Two assumptions can be set here. According to the assumed tree of pollutants (Figure 4), the greatest number of pollution sources is found between the measuring stations 1 Batrage and 2 Rudnica at distance of about $128 \mathrm{~km}$. Since BOD difference is between minimum and maximum value,
BOD consumption is smaller in Rudnica than in Batraga (Figure 7) and it can be assumed that the river Ibar in that course has capacity to overcome the possible entered organic matter in aquatic body. Between the measuring point 2 Rudnica and measuring point 3 Raska, the following pollutants, di 
rectly discharged into the river Ibar, were found:

- Landfill Rudnica;

- Production of refractory materials Raska;

- Communal waste water Rudnica;

- Communal waste water Raska;

- Food and textile industry Raska;

- Wood processing industry Raska.

Distance between the measuring stations 2 Rudnica and 3 Raska is shorter than distance of all measuring stations. If it is assumed that the level of organic pollutants input is similar along the whole investigated course of the river Ibar, and taking into consideration that the analysis presented in Figure 6 shows the greatest differences of minimum and maximum values of BOD consumption between these two stations, it can be concluded that the aquatic system itself is not able to react by self-purification at this distance.

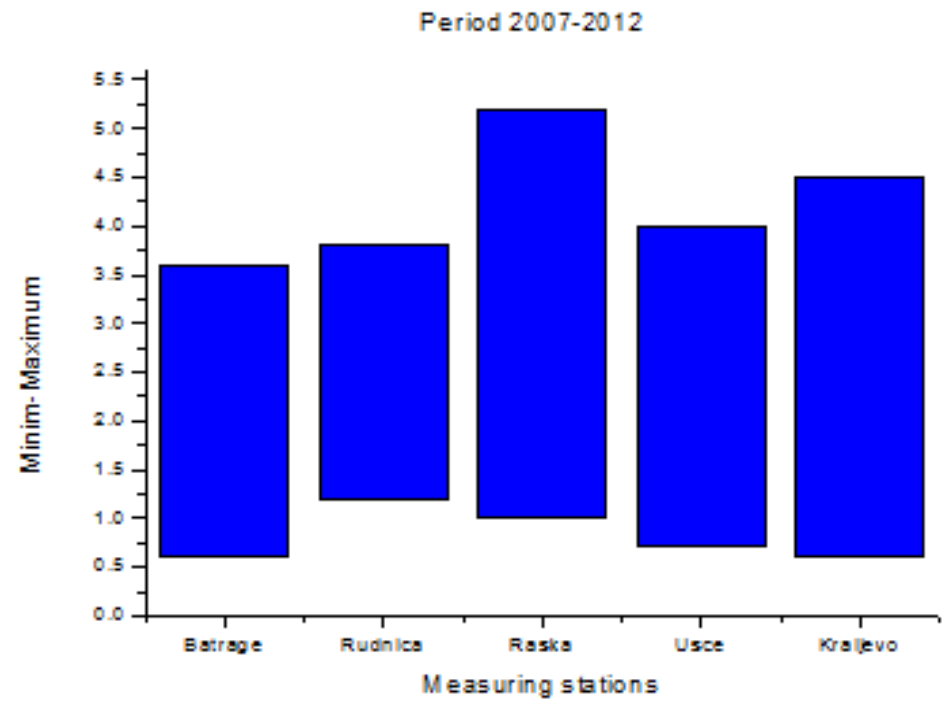

Figure 7 Differences between minimum and maximum mean annual values of BOD -5 for the period from 2007 to 2012

According to the given results it is evident that the studied ecosystem depends on the water quantity and time needed to move that quantity from one place to another or from different processes of self-purification, aeration, reaeration, sedimentation and others that cannot be quantified on the basis of the existing results. It would be interesting to ask whether the relation between cumulative SWQI at the measuring station and time distribution of oxygen consumption for the same measuring point can define an index of self-purification the aquatic environment or at least to define minimum required value of BOD that is necessary to maintain the water quality at the required level quantified by SWQI.

The river Ibar is not able to overcome the additional organic load, either by pollutant or some other, at short distance between the measuring stations Rudnica and Raska. It means that there is not enough potential for overcoming the additional organic load which occurs after Rudnica. Further variations, differences of minimum and maximum values, indicate that there are the new 
organic matter loads in the river Ibar and that the aquatic body itself by its potential and sufficient length has potential to mitigate the effect of organic load to a certain degree.

If we now go back to calculated quality indices of SWQI, presented in Table 1, we can see that they present more important annual fluctuations in values, it means, according to such calculated annual values, that the aquatic body had minimum variations of water quality along the whole length.

\section{CONCLUSION}

Based on the presented research, it can be concluded that SWQI is a clear indicator of water quality, but, like all integral parameters, does not indicate the processes along aquatic system or water basin. Analysis of the results showed that SWQI should be supplemented by index of selfpurification or by index of pollution along the watercourse length that would originate from the tree of pollutants.

In the world as well as here, there are automatic measuring stations, but their maintenance is very expensive and requires trained and qualified technicians. Another problem is analysis of the measured data and in some way generalization the model of watercourses behavior. In recent decades, the situation with watercourses has become complicated, their use as landfills that are practically impossible to control as well as specification the pollutants that should be monitored. It is obvious that in this area, a part from great number of measurement data, work on the processing methodology, in order to improve the entire system of water resources management, that is, watercourses, should continue. Whether it is necessary to develop a system for early warning the existence of sudden uncontrolled pollution or developing models for water courses at appropriate locations is a matter of applied research and generally the way of viewing water as a resource and as a potential source of drinking water [8].

The solution in terms of methodology would be setting up 24 hourly measurement probes that would in real-time on a specific measuring station monitor the changes of parameters according to which SWQI is calculated. It is clear that such system would also define the system of early warning the existence of pollution the aquatic systems, which is in some way the "Holy Grail" of all participants in the management system of water resources and water basins [9].

\section{REFERENCES}

[1] Jovanić P., Bovan Lake, Monitoring of Water Quality for the Period 20072013, Final Report, University of Belgrade, Institute for multidisciplinary research, Belgrade, 2013;

[2] Alain F. Zuurieno E., and Elphick C., A Protocol for Data Exploration to Avoid Common Statistical Problems, Methods in Ecology \& Evolution 2010, 1, 3-14;

[3] Naddeo V., Zarra T., Belgiorno V., European Procedures to River Quality Assessment, Global NEST Journal, Vol. 7, No 3, pp 306-312, 2005;

[4] Dedijer A., Mitrović-Josipović, M., Radulović, E., Dimić, B., Marić, L., Krunić-Lazić, M., Špegar, G., Vidojević, D., Jovanović, M., Veljković, N., Jovičić, M., Redžić, N., Popović, S., Pajčin, N., Lekić, D., Popović, T., Mijović, A., Environment in Serbia: An Indicator - Based Review, Serbian Environmental Protection Agency, 2007, ISBN 978-86-84163-34-1;

[5] Republic Hydro Meteorological Service of Serbia, Hydrological Yearbook from 2007 to 2012, Belgrade; 
[6] N. Elezović, Master Thesis, University in Belgrade, Faculty of Mining and Geology, Belgrade, 2006;

[7] N. Elezović, PhD Thesis, University of Niš, Faculty for Technology Leskovac, 2014, to be publish, in Serbian;

[8] Lj. Takić, I. Stamenković, N. Živković, N. Elezović, Water Pollution of the
River Ibar in the Function of Indicator of Environmental Situation, Journal Ecologica 70/2013, Belgrade 2013;

[9] N. Elezović, V. Šerifi, R. Cvejić, Analysis Water and Air Quality in Mitrovica District, $11^{\text {th }}$ International Conference Research and Development in Mechanical Industry, RaDMI 2011, Proceedings Vol. 2. 


\begin{tabular}{ll}
\hline \hline $\begin{array}{l}\text { INSTITUT ZA RUDARSTVO I METALURGIJU BOR } \\
\text { UDK: } 622\end{array}$ & $\begin{array}{l}\text { ISSN: 2334-8836 (Štampano izdanje) } \\
\text { ISSN: 2406-1395 (Online) }\end{array}$ \\
\hline \hline & \\
UDK: $628.161 .1: 681.51(045)=163.41$ & DOI:10.5937/MMEB1501117E
\end{tabular}

Nataša Elezović, Ljiljana Takič**, Predrag Jovanić ${ }^{* * *}$

\section{NOVI PRISTUP ANALIZI I MODELOVANJU KVALITETA VODE}

\section{Izvod}

Vodotokovi predstavljaju poseban slučaj vodnih basena. Bez obzira na način njihovog ispitivanja još uvek se traži pogodan način obrade sakupljenih parametara kvaliteta vode. Pravac istraživanja je definisana okvirna EU direktiva za vodna tela. Uzimajući u vidu postojeće metode analize kvaliteta vode, $u$ radu je prikazan predlog nove metode modelovanja ponašanja vodnog tela. Za osnovu su poslužila merenja na pet stanica na reci Ibar u vremenskom periodu od 2007 - 2012. godine. Osnova metode se bazira na multivarijabilnoj analizi nejednako vremenski raspoređenih mernih podataka. Osnova je bila korelaciona analiza koja je definisala zavisne parametre za određivanje SWQI indeksa. Analize su pokazale da se dobijeni rezultati mogu koristiti za uspostavljanje integralnog praćenja kvaliteta vode akvatičnog sistema Ibra. Takođe, ukazali su i na pravce unapređenja merenja i analize.

Ključne reči: modelovanje, vodeni baseni, SWQI, merenja BPK-5

\section{UVOD}

Ljudi su se razvili od psihološko relativno beznačajnih potrošača do domišljatih, intelektualnih bića i geohemijskih korisnika spoljnih izvora energije i materijala za građenje svoje civilizacije i povećanje dominacije. Ljudi troše 10 do 20 puta (na severnoj hemisferi 50 do 100 puta) više energije nego što je potrebno za njihov metabolizam. Poremećaj vodenog okruženja indirektno uzrokovano energetskom potrošnjom, može da nadmaši onu koja uzrokuje izbacivanje izlučevina (slika 1). Većina energije koju industrijsko društvo koristi kao svoju prednost (pravljenje toplote, upravljanje pejzažom, gradskom strukturom, poljoprivredom, šumarstvom, geološkim istraživanjima, građenjem brana) na kraju utiče i narušava ekosistem. Ljudi - kao kopnena bića - direktno utiču prvenstveno na kopnenu okolinu; ali, pošto su kopno i vodeni ekosistem povezani i zbog osetljivosti ovog drugog, naglašen uticaj civilizacije na ekologiju se prvo odražava na vodeni ekosistem. Mnoge posledice rasipanja energije su primetne i u atmosferi, koja se ponaša kao efikasana pokretna traka za mnoge zagađivače. Ljudska moć da remeti okolinu, teži da ide ispred tehnoloških mogućnosti za odgovor na uticaj na okolinu [1].

Ekosistem može da se definiše kao jedinica okoline u kojoj se, kao rezultat ulaza sunčeve energije, biološka zajednica (primarni proizvođači, potrošači i razlagači) održava; protok energije se koristi da se organizuje sistem i praćen je ciklusima vode, nutrienata i drugih elemenata i životnim

\footnotetext{
*Fakultet tehničkih nauka, Kosovska Mitrovica, Univerzitet u Prištini, e-mail: elezkm@yahoo.com *** Tehnološki fakultet, Leskovac, Univerzitet u Nišu

**** Institut za multidisciplinarna istraživanja, Univerzitet u Beogradu
} 
ciklusom kroz različite korisnike hrane na različitim nivoima. Članovi ekosistema su povezani različitim povratnim spregama (homeostaza) i kao takvi prilagođeni koegzistenciji u svrhu zajedničkog napredovanja. Mreža kontrola i ravnoteža uključuje mnoštvo prenosa organskih i neorganskih supstanci - mrežu hrane, nutrienata, alelohemikalija - i stvara od ekosistema funkcionalnu jedinicu [2].

Drugi zakon termodinamike kaže da će svaki spontani proces biti praćen porastom entropije:

$\mathrm{d} S$ (izvor, odvod) $+\mathrm{d} S($ ekosistem $) \geq 0$.

Zbog uslova d $S$ (izvor, odvod) $>0$, entropija ekosistema može da opada, tj. da bude: $-\mathrm{d} S($ ekosistem $) \leq \mathrm{d} S$ (izvor, odvod).

Opadanje se ogleda u sređivanju ekosistema i prisustvu neverovatno visokog sjedinjavanja energije kao živih bića. Njihova organizacija je uređena na račun povećanja entropije u okolini.

Do sada smo nastojali da različitim subjektima priđemo na kvantitativan i rigorozan način. U ovom poglavlju, naprotiv, često ćemo morati da se oslonimo na kvalitativne, a često i spekulativne argumente, jer je naše poimanje elastičnosti vodenog ekosistema ozbiljno ometeno nedostatkom teorijskih i dovoljnih empirijskih informacija o efektima fizičkih i hemijskih poremećaja vodenih ekosistema [3].

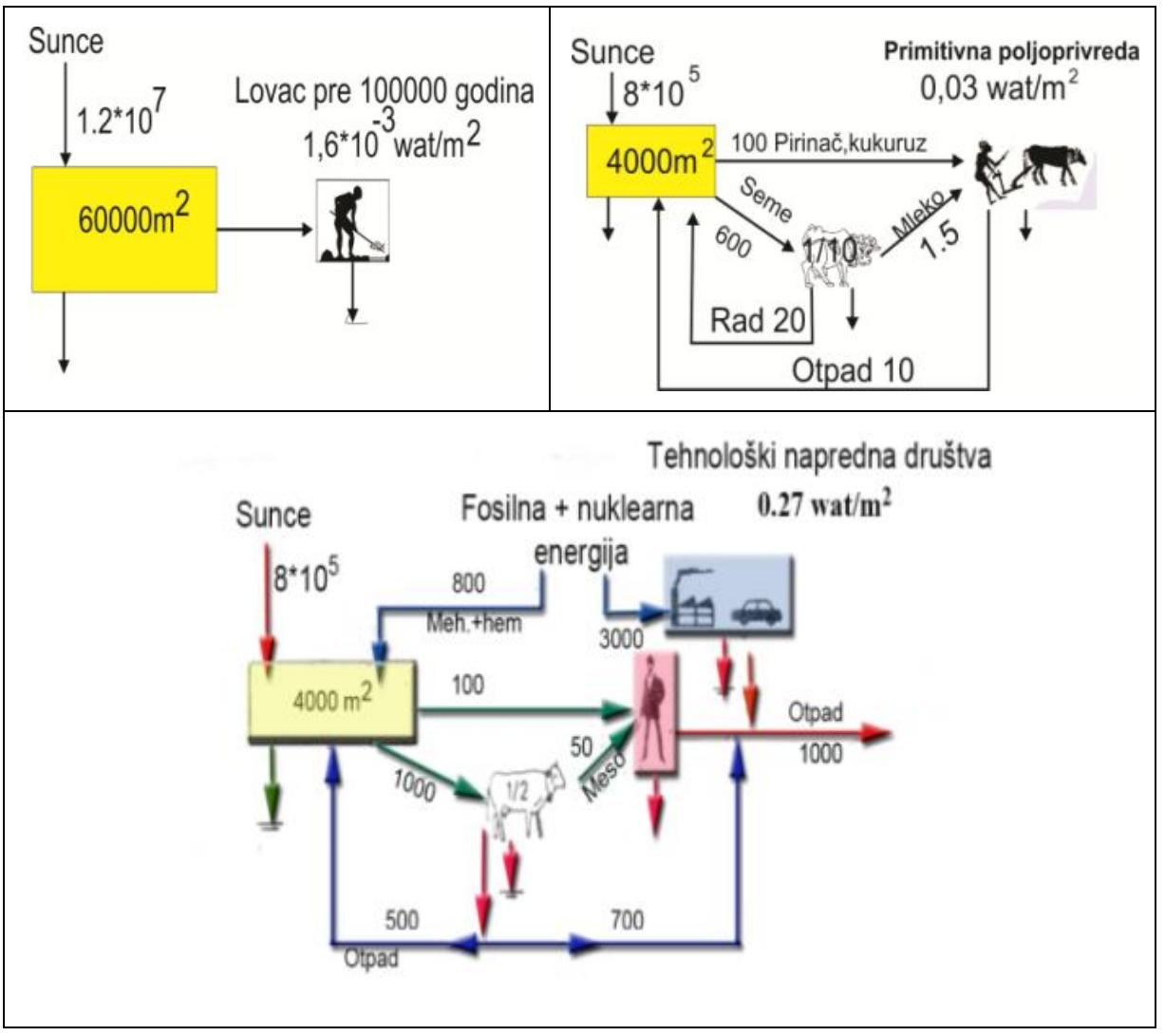

SI. 1. Potrebe za energijom i zemljom kod primitivnog i modernog čoveka 
Za održavanje naše kulture i civilizacije i poboljšanje kvaliteta života, a posebno za proizvodnju hrane za sve veću svetsku populaciju, potrebno je da nastavimo da zavisimo od upotrebe tehnologije i energije. Društveni kriterijumi i rastući pritisak za socijalnom jednakošću moraju uporedo utvrditi naučni i tehnološki razvoj, naučni i tehnološki razvoj.

Vodotokovi predstavljaju poseban slučaj vodnih basena, prvo sa aspekta analize vodotokova predstavljaju skup interakcija biodiverziteta i ljudskog delovanja koji je pokretan u prostoru. Znači, ukoliko dođe do neke promene na jednom delu vodotoka za određeno vreme usled mešanja ili distribuira $\mathrm{u}$ po celom vodnom telu ili se prenose na drugo mesto. Samim tim praćenje kvaliteta vode ili opšte rečeno dešavanja u odgovarajućem vodotoku predstavljaju problem. Vodotokovi i sam kvalitet vode trenutno se meri klasičnim uzorkovanjem i određivanjem vrednosti izabranog broja parametara.

Bez obzira što naša zemlja spada $u$ oblasti sa relativno razvijenom vodnom mrežom nije sigurno da, ukoliko se nastavi ovakav trend zagađivanja, i sama voda za piće će postati nedostajajući resurs.

Za sada važeći sistem merenja kvaliteta vode, indeks kvaliteta vode i njegova varijacija primenjena $u$ našoj zemlji je SWQI (SERBIAN WATER QUALITY INDEX) koja je razvila Agencija za zaštitu životne sredine. Ideja postavljanja ili definisanja ovakvog indeksa je da se jednim brojem jasno ukaže na kvalitet vodnog tela kako bi postao jasan i ukazivao na eventualno postojeće probleme široj zajednici. Izbor parametara koji se koriste za određivanje indeksa kvaliteta vode oslikava najbliže kvalitet vode, pri čemu svaki od tih parametara ima različitu težinu pri analizi. Sam taj sistem ukazuje na postojanje izvesne „pristrasnosti” indeksa kvaliteta vode, što ne mora da znači da sam indeks nije dobar, ali ukazuje na još uvek nedovoljnu eksplicitnost samog indeksa [4].

Drugi problem je nepostojanje metodologije reprezentativnog uzorkovanja. Uzorkovanje predstavlja ključni deo svake metodologije merenja. Ako se pogleda razvoj merne tehnike, merne metodologije, obrade rezultata kao i modelovanje, sve pomenute oblasti su doživele značajna unapređenja u samoj metodologiji, u kvalitetu itd., sem u načinu uzorkovanja samog entiteta za analizu.

Problem analize kvalieta vode kod vodotokova je uvećan činjenicom da uzorak važi samo za lokaciju i samo za vreme uzorkovanja (tačkasti), tako da je veoma značajan vremenski period između uzorkovanja i analize uzetog uzorka.

\section{METODOLOGIJA \\ (PRIKUPLJANJE I OBRADA PODATAKA, MODELOVANJE)}

U cilju analize i mogućih unapređenja integralnog praćenja kvaliteta vodotokova urađena je analiza postojećih podataka za reku Ibar i pet mernih stanica za period 2007 - 2012. godine i odgovarajućih izračunatih SWQI. U radu je izvršena analiza podataka za reku reku Ibar i pet mernih stanica za period 2007 - 2012. godina na osnovu izračunatih vrednosti SWQI. Cilj rada je bio da se na bazi analza podataka u vremenskom period od 2007 - 2012. godine oceni mogućnost unapređenja integralnog praćenja kvaliteta toka reke Ibar.

Rezultati su bazirani na merenjima, RHMZ Srbije, odnosno Agencije za zaštitu životne sredine. U tabeli 1 prikazane su srednje godišnje vrednosti parametara koje se koriste za izračunavanje SWQI u periodu 2007 - 2012. godine, kao i srednje godišnje vrednosti SWQI za isti period [5]. 
Tabela 1. SQWI kvalitet vode reke Ibar za period 2007 - 2012. godine

\begin{tabular}{|l|c|c|c|c|c|c|}
\hline Parametri & $\mathbf{2 0 0 7}$ & $\mathbf{2 0 0 8}$ & $\mathbf{2 0 0 9}$ & $\mathbf{2 0 1 0}$ & $\mathbf{2 0 1 1}$ & $\mathbf{2 0 1 2}$ \\
\hline Temperatura $\left({ }^{\circ} \mathrm{C}\right)$ & 12,78 & 12.47 & 11.00 & 11.31 & 11.46 & 11.79 \\
\hline pH vrednost & 8,43 & 8.42 & 8.36 & 8.24 & 8.47 & 8.48 \\
\hline $\begin{array}{l}\text { Elektroprovodljivost } \\
(\mu \mathrm{S} / \mathrm{cm})\end{array}$ & 416,20 & 448.62 & 428.73 & 433.33 & 447.08 & 432.50 \\
\hline $\begin{array}{l}\text { Zasićenost kiseonikom } \\
(\%)\end{array}$ & 99,14 & 93.49 & 94.22 & 99.63 & 95.5 & 95.43 \\
\hline BPK $(\mathrm{mg} / \mathrm{l})$ & 3,03 & 2.76 & 2.30 & 2.37 & 2.12 & 2.02 \\
\hline $\begin{array}{l}\text { Suspendovane materije } \\
(\mathrm{mg} / \mathrm{l})\end{array}$ & 21,05 & 25.78 & 24.24 & 21.45 & 26.95 & 27.41 \\
\hline $\begin{array}{l}\text { Ukupni oksidi azota } \\
(\mathrm{mg} / \mathrm{l})\end{array}$ & 1,73 & 2.10 & 1.42 & 0.93 & 1.21 & 0.86 \\
\hline Ortofosfati $(\mathrm{mg} / \mathrm{l})$ & 0,11 & 0.14 & 0.11 & 0.10 & 0.11 & 0.09 \\
\hline Amonijum $(\mathrm{mg} / \mathrm{l})$ & 0,02 & 0.01 & 0.03 & 0.25 & 0.14 & 0.24 \\
\hline $\begin{array}{l}\text { Koliformne bakterije } \\
(\mathrm{u} 100 \mathrm{ml})\end{array}$ & 13483,33 & 15274.33 & 15150.00 & 14703.33 & 7714.60 & 174.65 \\
\hline SQWI & $\mathbf{7 8}$ & $\mathbf{7 7}$ & $\mathbf{8 1}$ & $\mathbf{7 8}$ & $\mathbf{8 1}$ & $\mathbf{8 2}$ \\
\hline
\end{tabular}

\section{REZULTATI I DISKUSIJA}

Termin „korelacija” potiče od latinske riječi „correlatio“ - međuodnos. Pod pojmom korelacione analiza podrazumeva se merenje nivoa stohastičkih međuzavisnosti tj. merenje stepena slaganja varijacija posmatranih veličina u relativnom smislu.

$\mathrm{Za}$ merenje stepena korelacije (zavisnosti) između dve promenljive koristi se koeficijent linearne korelacije ili indeks korelacija za nelinearne regresione modele. Između regresione i korelacione analize postoje uske veze. U praksi se najčešće srećemo sa pojavama koje, utiču jedna na drugu, i prema tome značajno je ispitivanje postojanja međusobnih veza. Ispitivanje može da se vrši na bazi osnovnog skupa ili na bazi uzoraka o osnovnom skupu a sve to nosi određen rizik greške koji se može kontrolisati. Funkcionalna veza između pojava može da bude deterministička (strogo određena - matematička) ili stohastička. Stohastička zavisnost između promjenjivih se ispoljava u masi slučajeva, kao srednji odnos i ima veću ili manju varijaciju individualnih slučajeva u odnosu u funkcionalnu vezu. Stohastička zavisnost izražava se uslovno matematičkim funkcijama koje najbolje aproksimiraju dati emparijski podaci uz određenu grešku izbora. Cilj regresione analize je da se odredi funkcionalna veza između posmatranih pojmova, a korelacione da ukase na postojanje veza izmedju analiziranih entiteta.

Korelaciona analiza zavisnosti parametara i SWQI za isti period prikazana je na slici 2 i u tabeli 2 [6,7]. 


\section{Correlations (Spreadsheet1 $12 \mathrm{v}^{*} 10 \mathrm{c}$ )}

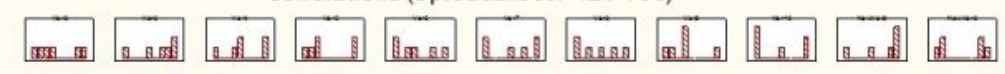

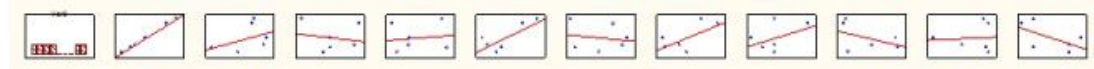

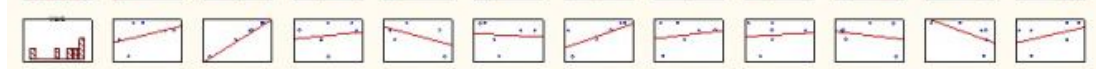

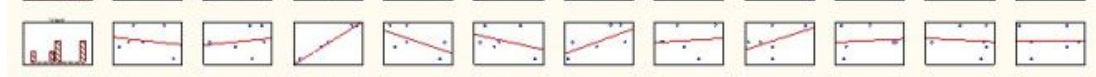

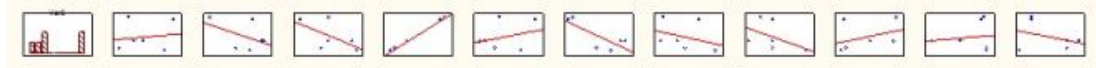

.

四

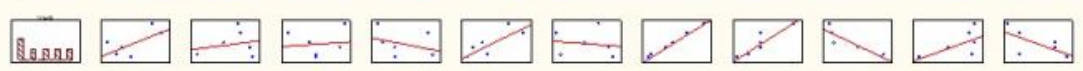

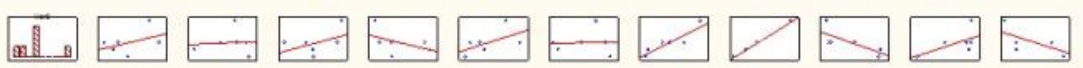

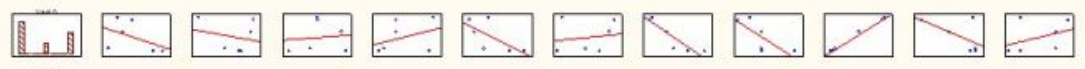

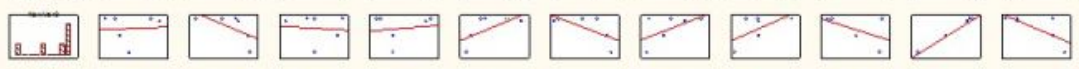

出口 $\because \because \because \square \square \square \square \square$

Sl. 2. Grafički prikaz korelacione matrice

Tabela 2. Korelaciona analiza SWQI i parametara za izračunavanje

\begin{tabular}{|c|c|c|c|c|c|c|c|c|c|c|c|}
\hline & $\begin{array}{c}\mathbf{T} \\
\left({ }^{\circ} \mathbf{C}\right)\end{array}$ & pH & $\begin{array}{l}\text { Elektp. } \\
(\mu \mathrm{S} / \mathrm{cm})\end{array}$ & $\begin{array}{l}\text { Zas. } \\
\text { kise. } \\
(\%)\end{array}$ & $\begin{array}{l}\mathrm{BPK}_{5} \\
(\mathrm{mg} / \mathrm{l})\end{array}$ & $\underset{(\mathrm{mg} / \mathrm{l})}{\text { Susp. m. }}$ & $\begin{array}{c}\text { Ukupni } \\
\text { N (mg/l) }\end{array}$ & $\begin{array}{l}\text { Orto P } \\
\text { (mg/l) }\end{array}$ & $\begin{array}{c}\mathrm{NH}_{3} \\
(\mathbf{m g} / \mathbf{l})\end{array}$ & $\begin{array}{l}\text { Kolifor. } \\
\text { bakter. }\end{array}$ & SWQI \\
\hline $\mathrm{T}\left({ }^{\circ} \mathrm{C}\right)$ & 1,00 & 0,42 & $-0,18$ & 0,14 & 0,78 & $-0,18$ & 0,65 & 0,43 & $-0,44$ & 0,07 & $-0,58$ \\
\hline $\mathrm{pH}$ & 0,42 & 1,00 & 0,16 & $-0,48$ & $-0,09$ & 0,68 & 0,20 & 0,08 & $-0,23$ & $-0,63$ & 0,42 \\
\hline $\begin{array}{l}\text { Elektp. } \\
(\mu \mathrm{S} / \mathrm{cm})\end{array}$ & $-0,18$ & 0,16 & 1,00 & $-0,59$ & $-0,37$ & 0,67 & 0,10 & 0.47 & 0,10 & $-0,09$ & $-0,01$ \\
\hline $\begin{array}{l}\text { Zas. kis. } \\
(\%)\end{array}$ & 0,14 & $-0,48$ & $-0,59$ & 1,00 & 0,29 & $-0,79$ & $-0,33$ & $-0,47$ & 0,37 & 0,14 & $-0,33$ \\
\hline $\begin{array}{l}\mathrm{BPK}_{5} \\
(\mathrm{mg} / \mathrm{l})\end{array}$ & 0,78 & $-0,09$ & $-0,37$ & 0,29 & 1,00 & $-0,64$ & 0,79 & 0,58 & $-0,68$ & 0,65 & $-0,82$ \\
\hline $\begin{array}{l}\text { Suspm. } \\
\text { m (mg/l) }\end{array}$ & $-0,18$ & 0,68 & 0,67 & $-0,79$ & $-0,64$ & 1,00 & $-0,13$ & 0,05 & 0,15 & $-0,66$ & 0,60 \\
\hline $\begin{array}{l}\text { Ukupni } \\
\mathrm{N}(\mathrm{mg} / \mathrm{l})\end{array}$ & 0,65 & 0,20 & 0,10 & $-0,33$ & 0,79 & $-0,13$ & 1,00 & 0,91 & $-0,91$ & 0,60 & $-0,63$ \\
\hline \begin{tabular}{|l} 
Orto P \\
$(\mathrm{mg} / \mathrm{l})$
\end{tabular} & 0,43 & 0,08 & 0,47 & $-0,47$ & 0.58 & 0,05 & 0,91 & 1,00 & $-0,75$ & 0,61 & $-0,63$ \\
\hline $\begin{array}{l}\mathrm{NH}_{3} \\
(\mathrm{mg} / \mathrm{l})\end{array}$ & $-0,44$ & $-0,23$ & 0,10 & 0,37 & $-0,68$ & 0,15 & $-0,91$ & $-0,75$ & 1,00 & $-0,59$ & 0,37 \\
\hline $\begin{array}{l}\text { Kolifor. } \\
\text { bakterije }\end{array}$ & 0,07 & $-0,63$ & $-0,09$ & 0,14 & 0,65 & $-0,66$ & 0,60 & 0,61 & $-0,59$ & 1,00 & $-0,73$ \\
\hline SQWI & \begin{tabular}{|l|}
$-0,58$ \\
\end{tabular} & 0,42 & $-0,01$ & $-0,33$ & $-0,82$ & 0,60 & $-0,63$ & $-0,63$ & 0,37 & $-0,73$ & 1,00 \\
\hline
\end{tabular}


Rezultati dobijeni korelacionom analizom i prikazanim u tabeli 2 pokazuju da ne postoji korelacija između merenih parametara i izračunate vrednosti SWQI. Jedina značajna korelacija postoji između BPK-5 parametra i SWQI. Sama ta analiza je interesantna, jer na osnovu tih parametara se računa SWQI i trebalo bi da postoji linearna analiza između merenih parametara i SWQI.

To znači da između mernih mesta $u$ vremenu postoje promene koje su nekontrolisane odnosno izazvane rezličitim uticajima ili što je veća verovatnoća različitim zagađivačima koji se nalaze duž vodotoka Ibra između mernih stanica. Iako se SWQI izračunava iz navedenih parametara korelacija postoji samo između BPK-5 i SWQI iako se indeks izračunava iz svih pomenutih. To je objašnjivo činjenicom da se svaki od para- metara računa sa odgovarajućom težinom koja remeti korelaciju. Samo postojanje korelacije između BPK-5 i SWQI ukazuje na činjenicu da brza procena SWQI indeksa može uraditi na osnovu praćenja promene vrednosti BPK-5, kao što je to prikazano na slici 3.

$\mathrm{Na}$ ovom mestu ne bi smo ulazili u diskusiju vrednosti težinskih faktora koji se unose za svaki parametar pri izračunavanju SWQI, kao i definisanju njihove vrednosti. S obzirom da je u osnovi ovog rada ideja o poboljšanju praćenja integralnog kvaliteta vodotokova odnosno reke Ibar. Analiziraćemo parametar BPK-5 kao mogući brzi pokazatelj SWQI indeksa. Za tu analizu koristili smo normalizovane srednje godišnje vrednosti BPK-5 i SWQI za period od 2007 - 2012. godine, prikazane na slici 3 [7].

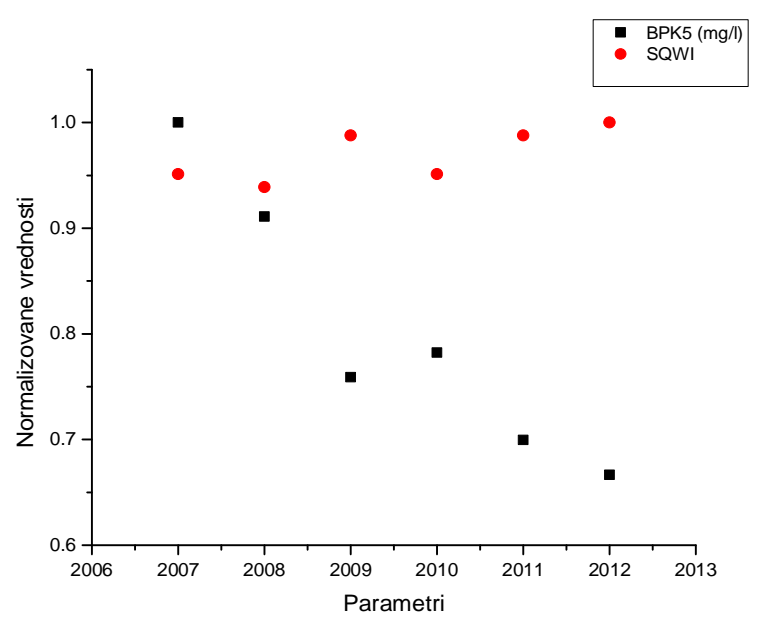

Sl. 3. Normalizovane srednje godišnje vrednosti BPK-5 i SWQI po celoj dužini Ibra

Kao što se sa slike vidi, promena vrednosti SWQI prati promenu vrednosti BPK5. Ta činjenica se može iskoristiti za define-sanje modela praćenja zagađivanja vodnog tela. Biološka potrošnja kiseonika pred-stavlja količinu kiseonika neophodnu za biološko razlaganje kontaminirane materije. Sa aspekta samoprečišćavanja vodotokova aeracija reaeracija su ključni procesi. Organskim zagađenjem akvatične sredine aktivira se niz bioloških aktivnosti (bakterije, alge i gljivice) koje dovode do pretvaranja organske materije u konačne neorganske proizvode. Reaeracija i BPK-5 kao dve osnovne reakcije u toku procesa samoprečišćavanja akvatične sredine predstavljaju osnov za određivanje prostorne i vremenske raspodele rastvorenog kiseo- 
nika odnosno bilansa kiseonika. Rezultanta ova dva procesa predstavlja realni sadržaj rastvorenog kiseonika duž celog vodotoka. Ako se analizira izračunavanje, metodologija ili model SWQI, ne može da se jasno definiše kako se kvantifikuje reaeracija akvatične sredine. Zbog toga je neophodno definisati i potencijalne zagađivače (pre svega organskim materijama) na ispitivanom vodotoku. Ako posmatra- mo raspodelu mernih stanica na vodnom telu možemo definisati okvirno i potencijalne zagađivače na lokacijama između mernih stanica. Time se definiše ,Stablo zagađivača" i lokacije potencijalnih mesta zagađivanja vodnog tela. Prikazano je stablo zagađivača na slici 4 [7], gde se vidi da između svake merne stanice postoji zagađivač većeg ili manjeg intenziteta.

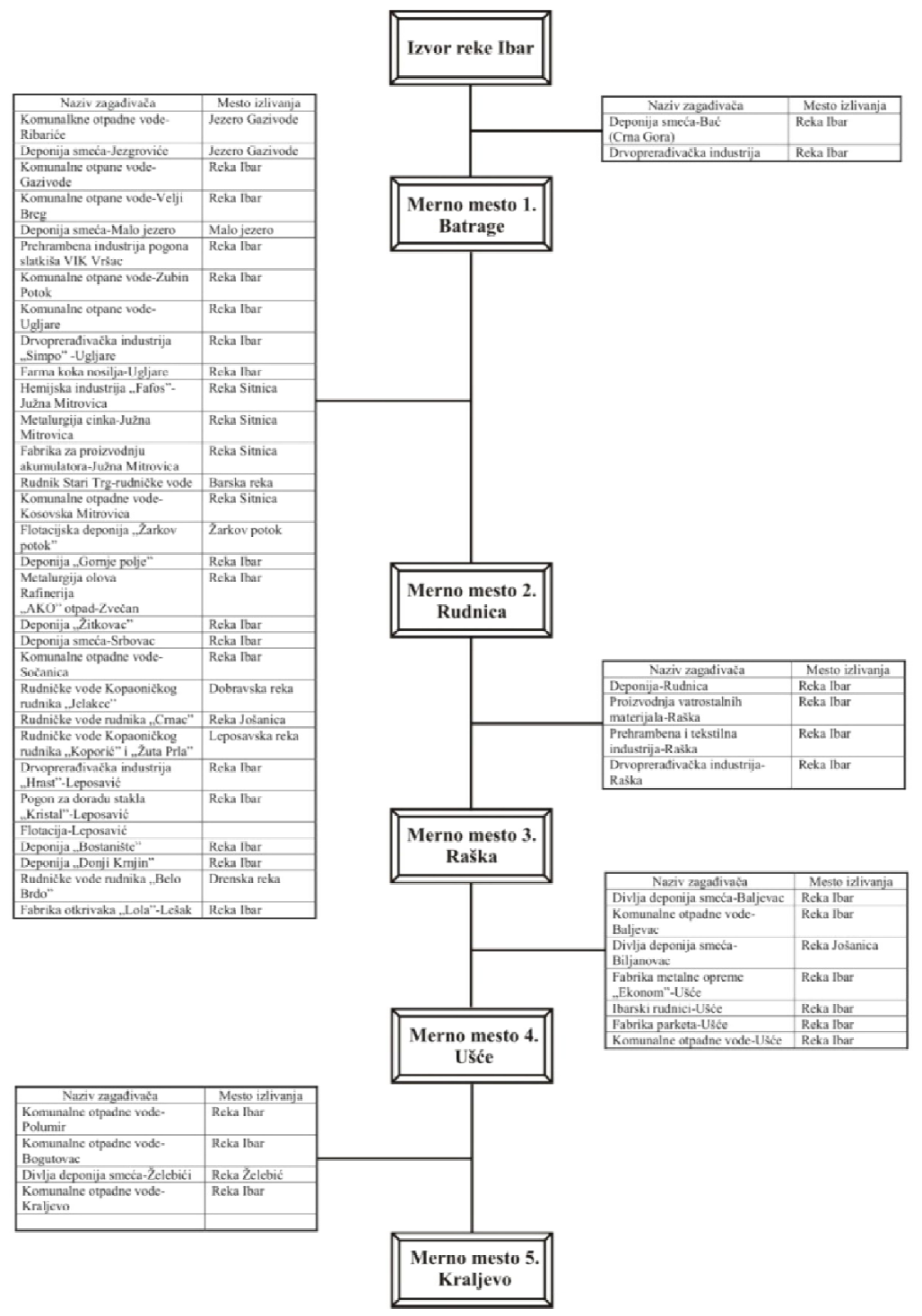

Sl. 4. Stablo zagađivača [7] 
Teško je odrediti nivo zagađenja jer ne postoje tačni podaci o količinama otpadnih materija koje dolaze. Kao što se može videti postoji opravdana pretpostavka da će se neki od parametara menjati kao i njihove varijacije tokom vremena a da pri tome to neće znatno uticati na vrednost SWQI. Jedan od reprezentativnih parametara za kvalitet vode je biološka potrošnja kiseonika (BPK-5). Stepen zagađenosti vode organskim jedinjenjima definisan je količinom kiseonika potrebnog za oksidaciju prisutnih biloški razgradivih sastojaka vode koju vrše aerobni mikroorganizmi. Ta količina kiseonika naziva se biohemijska potrošnja kiseonika (BPK). Potrebna količina proporcionalna je prisutnoj količini organskih materije. Temperatura i vreme razgradnje utiču na veličinu $\mathrm{BPK}, \mathrm{tj}$. sa povećanjem temperatura raste $\mathrm{i}$ brzina i potrošnje kiseonika (biohemijska oksidacija). Smatra se da je potrebno 5 dana kako bi se razgradio veći deo (70-80\%) prisutnih organskih materija, i to u tami, na stalnoj temperaturi vode od $20^{\circ} \mathrm{C}$, zbog čega se i naziva BPK. BPK nije specifični zagađivač, već mera količine kiseonika neophodne za bakterije i ostale mikroorganizme uključene u stabilizaciji raspadanja organske materije tokom određenog vremenskog perioda. BPK je mera upotrebe kiseonika, ili potencijalne upotrebe kiseonika. Tekući otpad sa velikim BPK-om može biti štetan po reku ako je upotreba kiseonika dovoljno velika da uzrokuje anaerobična stanja.

Analiza promene tokom vremena po dužini vodotoka prikazana je na slici 5 [7], pokazuje povećanje BPK kako se ide prema ušću Ibra u Zapadnu Moravu tako da slobodno možemo reći da se količina organskog zagađenja povećava.

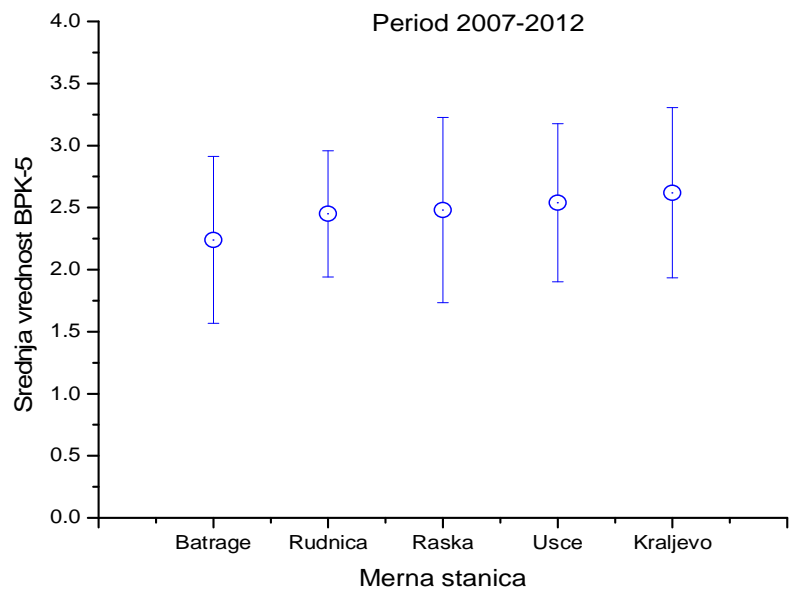

Sl. 5. Srednje godišnje vrednosti BPK-5 za period 2007-2012. godinu

Slika 5 pokazuje srednje godišnje vrednosti BPK za period 2007 - 2012. godine po mernom mestu sa standardnim odstupanjima tokom godine.

Ono što je vidljivo sa grafika je da postoji trend porasta srednje vrednosti po mernim stanicama prema ušću Ibra u Zapadnu
Moravu. Takođe, ako se posmatra varijacija merenja (standardna devijacija) moguće je videti da i ta odstupanja tokom perioda od 6 godina variraju po mernim stanicama ili lokacijama čime definisanjem stable zagađivača dobija na svom značaju, jer vremenske varijacije izmerenih parametara ukazuju 
na povećano ili smanjeno zagađenje (organskih materija) na tom mernom mestu i definisanom vremenskom periodu (2007 - 2012. godine.).

Međutim, ako analiziramo koeficijent varijacije, promene BPK tokom vremena i na mernim mestima vidimo da ta promena nije linearna, što znači da uključuje i slučajnog nekontrolisanog zagađenja između mernih stanica.

Statistička analiza promene BPK za period 2007-2012. prikazana je u tabeli 3.

Tabela 3. Statističaka analiza vrednosti BPK5 za period 2007-2012. g.

\begin{tabular}{|l|c|c|c|c|c|c|c|c|c|}
\hline $\begin{array}{c}\text { Merno } \\
\text { mesto }\end{array}$ & $\begin{array}{c}\text { Srednja } \\
\text { vredn. }\end{array}$ & STD & $\begin{array}{c}\text { Stand. } \\
\text { greška } \\
\text { srednja } \\
\text { vredn. }\end{array}$ & Varijac. & $\begin{array}{c}\text { Koef. } \\
\text { varijac. }\end{array}$ & $\begin{array}{c}\text { Sred. } \\
\text { vredn. } \\
\text { absol. } \\
\text { odst. }\end{array}$ & Min. & Medij. & Max. \\
\hline Batrage & 2,24 & 0,672 & 0,084 & 0,452 & 0,299 & 0,524 & 0,6 & 2,23 & 3,6 \\
\hline Rudnica & 2,45 & 0,509 & 0,072 & 0,259 & 0,207 & 0,382 & 1,2 & 2,45 & 3,8 \\
\hline Raska & 2,48 & 0,747 & 0,086 & 0,558 & 0,300 & 0,581 & 1 & 2,3 & 5,2 \\
\hline Usce & 2,54 & 0,637 & 0,078 & 0,405 & 0,250 & 0,511 & 0,72 & 2,6 & 4 \\
\hline Kraljevo & 2,62 & 0,686 & 0,070 & 0,471 & 0,261 & 0,508 & 0,6 & 2,5 & 4,5 \\
\hline
\end{tabular}

Grafički prikaz razlike minimalne i maksimalne vrednosti BPK po mernim mestima prikazana je na slici 6 [3]. Tu se vidi da su najviše razlike u periodu 2007 2012. godine izmerene na mernoj stanici Raška.

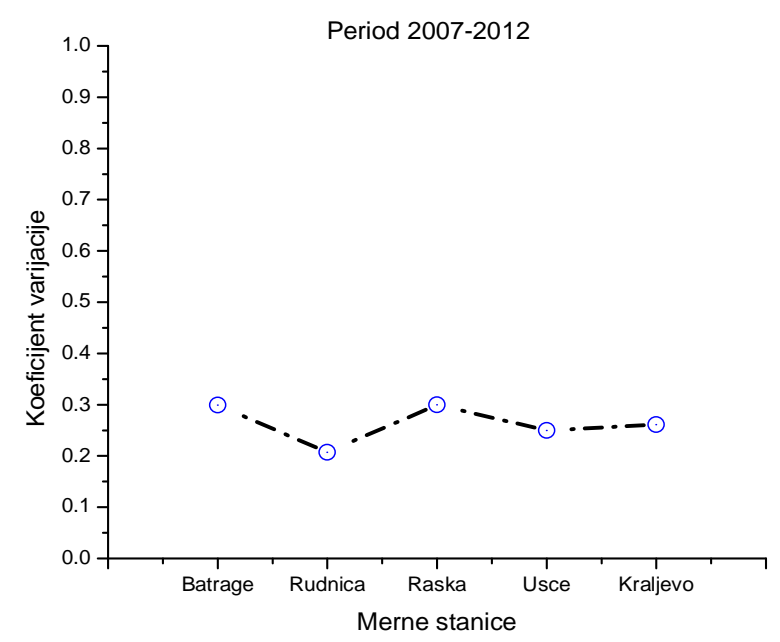

Sl. 6. Razlika minimalne maksimalne vrednosti BPK-5 po mernim mestima

Ovde možemo postaviti dve pretpostavke. Prema pretpostavljenom stablu zagađivača (slika 4) najveći broj izvora zagađenja se nalazi između mernih stanica 1 Batrage i 2 Rudnica čije je rastojanje oko
128 km. Pošto je BPK razlika između minimalne i maksimalne, potrošnja BPK manja u Rudnici nego u Batragama (slika 7) možemo pretpostaviti da Ibar u tom toku ima kapacitet da savlada eventualno unetu organsku 
materiju u vodnom telu. Između mernog mesta 2 Rudnice i mernog mesta 3 Raška nalaze se sledeći zagađivači koji se direktno izlivaju u Ibar:

- Deponija Rudnica

- Proizvodnja vatrostalnih materijala Raška

- Komunalne otpadne vode Rudnica

- Komunalne otpadne vode Raška

- Prehambena i tekstilna industrija Raška

- Drvoprerađivačka industrija Raška
Rastojanje između mernih stanica 2 Rudnica i 3 Raška je najkraće od rastojanja svih mernih stanica. Ako pretpostavimo da je nivo unosa organskog zagađivača sličan na celom ispitivanom toku reke Ibar, i imajući u vidu da analiza prikazana na slici 6 pokazuje da se najveće razlike minimalne $\mathrm{i}$ maksimalne vrednosti potrošnje BPK između ove dve stanice, možemo zaključiti da sam akvatični sistem nije u stanju da reaguje samoprečišćavanjem na ovom rastojanju.

Period 2007-2012

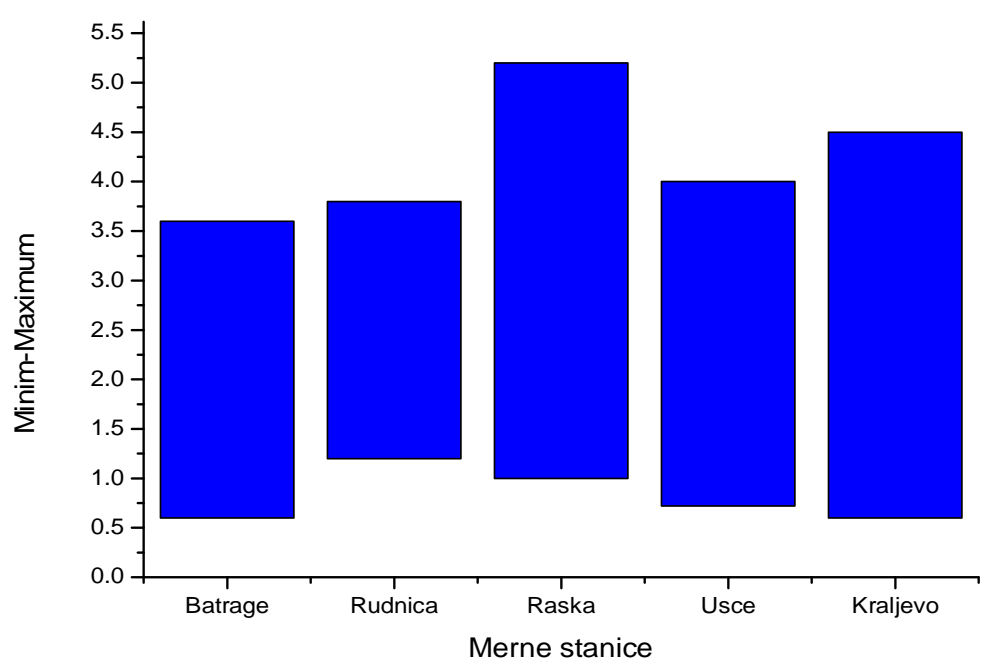

Sl. 7. Razlika između minimalne i maksimalne vrednosti srednjih godišnjih vrednosti BPK-5 za period 2007 - 2012. godine

Iz prikazanih rezultata sasvim je jasno da ispitivani ekosistem zavisi od količine vode $\mathrm{i}$ vremena potrebnog da se ta količina premesti sa jednog mesta na drugo, odnosno i od različitih procesa samoprečišćavanja, aeracije, reaeracije, sedimentacije i ostalih koje je nemoguće kvantifikovati na osnovu postojećih rezultata. Ovde bi bilo interesantno postaviti pitanje da li je odnos između zbirnog SWQI na mernoj stanici i vremenske raspodele potrošnje kiseonika za isto merno mesto, mogu da definišu neku vrstu indeksa samoprečišćavanja akvatične sredine ili bar da je definišu minimalnu potrebnu vrednost BPK koja je neophodna da se održi kvalitet vode na zahtevanom nivou koji je kvantifikovan SWQI.

Dodatno opterećenje organsko, bilo zagađivača ili nekog drugog, na kratkom rastojanju između mernih stanica Rudnica i Raška, Ibar ne može da savlada, što će reći, nema dovoljno potencijala da sam savlada dodatno organsko opterećenje koje se očigledno javlja posle Rudnice. Dalje varijacije, 
razlike minimalnih i maksimalnih vrednosti, ukazuju da dolazi do novih opterećenja organskom materijom u Ibru, a da samo vodno telo svojim potencijalom i dovoljnom dužinom ima potencijal da donekle ublaži efekat organskog opterećenja.

Ako se sada vratimo na izračunate indekse kvaliteta SWQI, prikazanog u tabeli 1, vidimo da oni ne pokazuju značajnije fluktuacije godišnje u samim vrednostima, odnosno da po tako izračunatim godišnjim vrednostima, vodno telo praktično je imalo minimalne varijacije kvaliteta vode po celoj dužini.

\section{ZAKLJUČAK}

Iz prikazanog teksta pokazano je da je SWQI jasan pokazatelj kvaliteta vode ali da, kao i svi integralni parametri, ne ukazuje na procese duž akvatičnog sistema ili vodenog basena. Analiza rezultata je pokazala da je SWQI neophodno dopunuti ili sa indeksom „Samoprečišćavanje” ili indeksom zagađenja po dužini vodotoka koji bi proizašao iz stabla zagađivača.

U svetu, kao i kod nas, postoje automatski merne stanice, ali njihovo održavanje je izuzetno skupo i zahteva obučene i kvalifikovane tehničare. Drugi problem je sama analiza izmerenih podataka i na neki način generalizovanje modela ponašanje vodotokova. U poslednjih nekoliko decenija situacija u vodotokovima se komplikuje, njihovim korišćenjem kao deponije koje praktično nemoguće je kontrolisati kao i specificirati zagađivače koje treba pratiti. Očigledno je da ovoj oblasti, pored veklikog broja mernih podataka, treba još uvek raditi i na samoj metodologiji obrade, kako bi se unapredio čitav sistem upravljanja vodnim resursima odnosno vodotokovima. Da li treba razvijati sistem za rano upozorenje postojanja iznenadnog nekontrolisanog zagađivanja ili razvijati modele za vodotokove na odgovarajućim lokacijama je pitanje primenjenih istraživanja i uopšte načina posmatranja vode kao resursa i kao potencijalnog izvora vode za piće [8].

Rešenje u metodološkom smislu bi bilo postavljanje 24 časovnih mernih sondi koje bi u realnom vremenu na određenoj mernoj stanici pratile promene parametara na osnovu koje se računa SWQI. Jasno je da bi takvim sistemom bio i definisan sistem ranog upozorenja na postojanje zagađenja akvatičnog sistema, što je na neki način i „SVETI GRAL” svih učesnika u sistemu upravljanja vodnim resursima i vodenim basenima [9].

\section{LITERATURA}

[1] Jovanić P., Jezero Bovan, Praćenje kvaliteta vode za period 2012-2013. godine, Univerzitet u Beogradu, Institut za multidisciplinarna istraživanja, Beograd, 2013.

[2] Alain F. Zuurieno E., and Elphick C., A Protocol for Data Exploration to Avoid Common Statistical Problems, Methods in Ecology \& Evolution 2010, 1, 3-14.

[3] Naddeo V., Zarra T., Belgiorno V., European Procedures to River Quality Assessment, Global Nest Journal, Vol. 7, No 3, pp 306-312, 2005

[4] Dedijer A., Mitrović-Josipović, M., Radulović, E., Dimić, B., Marić, L., Krunić-Lazić, M., Špegar, G., Vidojević, D., Jovanović, M., Veljković, N., Jovičić, M., Redžić, N., Popović, S., Pajčin, N., Lekić, D., Popović, T., Mijović, A., ENVIRONMENT in Serbia: an indicator - based review, Serbian Environmental Protection Agency, 2007, ISBN 978-86-84163-34-1.

[5] Republički hidrometeorološki zavod Republike Srbije, Hidrološki godišnjak od 2007-2012. godine, Beograd. 
[6] N. Elezović, Magistarska teza, Univerzitet u Beogradu, Rudarsko geološki fakultet, Beograd 2006.

[7] N. Elezović, Doktorska disertacija, Univerzitet u Nišu, Tehnološki fakultet u Leskovcu, 2014, u pripremi.

[8] Lj. Takić, I. Stamenković, N. Živković, N. Elezović: „Zagađenje vode reke
Ibar u funkciji indikatora stanja ži-vothe sredine", časopis Ecologica 70/2013, Beograd 2013.

[9] N. Elezović, V. Šerifi, R. Cvejić, Analysis Water and Air Quality in Mitrovica District, $11^{\text {th }}$ International Conference Research and Development in Mechanical Industry, RaDMI 2011, Proceedings Vol.2. 